\title{
Sectoral Growth of Pakistan: Evidence from ARDL Approach
}

\author{
Muhammad Ajmair ${ }^{1}$, Muhammad Akram Gilal², \\ and Abdul Rahman Nizamani ${ }^{3 *}$
}

\begin{abstract}
In this research paper, we followed the general to specific approach for finding out the factors that determine sectoral growth in Pakistan. The objective was to see which of these factors have relevancy in explaining sectoral growth. Auto regressive distributed lag (ARDL) bound testing in coordination with the general to specific approach was applied for conducting the analysis. Results showed that foreign direct investment, inflation and remittances received that have relevancy in determining the services sector growth. The variables which have significant effect on agricultural sector growth are remittances received, gross national expenditures and inflation. External debt and domestic credit to private sector significantly determined industrial sector growth. Based on empirical results, it is recommended that relevant authorities should augment the factors that cause sectoral growth and control those factors that retard it.
\end{abstract}

Keywords: Economic Growth; Sectoral Growth; ARDL; Economy; Pakistan.

\section{Introduction}

Economic growth refers to rise in national income and is measured through GDP growth. It results from country's productive capacity and is an indicator of economy's capacity to produce more goods and services. Other factors that determine growth are human resources, natural resources, capital formation, technological developments, and social and political factors (Nitisha, 2002). Economic growth has direct or indirect links with living standards of people. An increase in output growth leads to rise in income and improves living standard of the people and is a source of employment in the country (Palmer, 2012).

Societies aspire for development which is results from economic growth. Countries spend their resources for ensuring sustainable economic growth. Due to its enormous importance, economic growth has remained a focus of attention of researchers and policy makers around the world. Hence, knowing sources of growth is an important question for many economists engaged in identifying growth enabling factors for countries like Pakistan to grow and develop fast (Gebru, 2015).

The overall economic growth results in from growth in major sectors of the economy. In Pakistan, the major contributing sectors to overall

1. Department of Economics, Mirpur University and Science and Technology, Pakistan.

2. Department of Economics, University of Sindh, Jamshoro, Pakistan.

3. Department of Economics, University of Sindh, Jamshoro, Pakistan.

*)Corresponding Author.

Email: a.nizamani@usindh.edu.pk 
economic growth are agricultural sector, industrial and services sector. Both industrial and services sectors contribute approximately 80 percent to the country's GDP. Rest of 20 percent is contributed by agricultural sector.

It is argued that rural and urban sector development is mainly interconnected with development of agriculture and industrial sector of the country. For the overall development, it is important to create competitive environment for all major sectors of the economy to grow (Singh \& Singh, 2016). Agriculture has both forward and backward linkages with industrial and services sectors and has a key role in determining overall growth. The inter-sectoral linkages analysis identifies agriculture as a major sector that determines economic activities in India (Singariya \& Naval, 2016). Like agriculture, services and industrial sector growth has important effect on overall growth of the country (Rashid, 2010).

In this research paper, auto regressive distributed lag (ARDL) approach for finding out factors determining sectoral growth in Pakistan. ARDL approach is adopted due to following reasons:

(a) It does not require to test integrating order of the variables.

(b) It can be applied on small sample size.

(c) Short-term and long-term, as well as relations are estimated simultaneously.

The first major factors affecting sectoral growth are determined from empirical sectoral growth literature around the world. Then general to specific approach is adopted for finding out which of these factors are relevant determinants of sectoral growth in Pakistan. Results showed relevancy of inflation, gross fixed capital formation and population growth for agriculture sector growth. Consumer price index and population growth caused the agriculture sector growth to increase. While gross fixed capital formation on agriculture sector growth is negative. Inflation, credit extended to private sector and gross national expenditures determine growth of industrial sector. Increase in inflation and foreign direct investment increase industrial sector growth. However, foreign direct investment and gross national expenditure are the factors that reduce industrial sector growth in Pakistan. Factors determining services sector growth are inflation, foreign direct investment and remittances received. Services sector growth is augmented by rise in foreign direct investment and remittances received. Inflation increase however, retard the sector growth in long run.

\section{Literature Review}

Economic growth and its determinants have always remained a focus of both theoretical and empirical economic growth literature. In such a literature, economic growth is proxied with gross domestic product (GDP). However, sectoral aspect of economic growth has not been given adequate attention in the existing literature. In this section, sectoral empirical sectoral growth literature is reviewed. 


\subsection{Services Sector Growth}

During the fiscal year 2014-15, the share of the services sector was $58.80 \%$. It may be divided into five sub-sectors: services at community level; defense and public administration; insurance and finance; retail trade and wholesale; and communications, storage, and transport. It is very necessary to examine factors affecting services sector growth as it is the largest contributor to economic growth. A few research papers have been found in the existing literature where the authors have focused the factors determining services sector growth.

Gordon and Gupta (2003) using ordinary least square and data from 1952 to 2000, finds entry in service sector, services sector exports; external trade and trade liberalization have major influence on services sector growth in India. Jain et al., (2015) applied ordinary least squares method on annual data from 2000 to 2012, to categorize the factors that affect services sector growth in India. They concluded that net of institutional investment, foreign direct investment, and imports have a positive impact on services sector growth while services sector exports, debt and institutional investment abroad have negative effect. Singh and Kaur (2014) employed vector autoregressive (VAR) and conclude positive effect of GDP per capita, foreign trade and domestic investment on services sector share in gross domestic product. $\mathrm{Wu}$ (2005), employed fixed effect and random effects method for finding out determinants of the services sector in India and China. Based on results. The author concluded that per capita income, urbanization and foreign demand for services have positive and significant impact on growth of the services sector in both countries.

\subsection{Agriculture Sector Growth}

Agricultural sector is one of the main contributors to gross domestic product. No doubt sectoral share of agricultural sector in GDP has decreased, but it has still a major role in economic growth of the country. It contributed $20 \%$ to GDP of the country in fiscal year 2014-2015. Since agriculture sector has substantial contribution to economic growth of the country: it is therefore necessary to know the factors determining its growth.

Odhiambo et al. (2004) using augmented neoclassical model and ordinary least square approach found relevancy of rainfall, real exchange rate; primary school enrollment; government expenditures; financial development, roads, trade ratio and import penetration in determining agriculture sector growth in Kenya. Ahmed and Heng (2012) followed autoregressive distributed lags (ARDL) method of estimation and concluded that fertilizers, human capital, credit to private sector and area under crop significantly affected agriculture sector productivity in Pakistan. According to Warr (2012) government expenditures, international spending on agricultural production; share of food crops in agricultural production; government assistance to the sector; agricultural extension; and rainfall have major effect on total factor productivity in agriculture sector in Indonesia. Khalidi and Sherazi (2013) showed that labor, capital and total productivity have major impact on valeu 
added of agriculture sector in Iran. Enu and Obeng (2013) indicated that labor force, real exchange rate, and real per capita income have significant effect on agricultural output in Ghana. Camelia and Burja (2015) focused the factors determining agriculture sector output in Romania after its integration into European Union. Results of the study pointed out that land under agriculture utilization, labor per hectare and average farm capital significantly affected agriculture sector growth of the country. Chebil et al., (2015) applied autoregressive distributed lags (ARDL) method of estimation and concluded that government expenditures on research and development, infrastructure development in rural areas like roads and irrigated area have relevancy in determining wheat output in Tunisia.

\subsection{Industrial Sector Growth}

Industrial sector is one of the major contributors to overall economic growth of the country. In 2014-15, industrial sector contribution in total GDP of the country was 20.30 percent. Industrial sector can further be divided into sub sectors including mining and quarrying, manufacturing both large and small; construction, and electricity and gas distribution. Industrial sector covers a reasonable portion of GDP therefore; it is necessary to find out the factors affecting its growth.

Kathuria et al., (2010) using panel data and Cobb Douglas production function found the significant effect of labor force on manufacturing sector productivity. However, capital stock effect appeared the insignificant. Sola et al., (2013) employed Solow growth model and used the panel ordinary least square method for finding out factors having significant effect on performance of manufacturing sector in Nigeria. Their results indicated relevancy of imports, exports, capacity utilization, investment having significant positive effect on manufacturing sector of the country. Otalu and Andreu (2015) assessed the determinants of industrial sector growth in Nigeria. They used Leontief input output model and applied co-integration and error correction technique. They found that capital, labor, real exchange rate, capacity utilization, trade openness $\left(t o_{t}\right)$ and electricity generation, education attainment, inflation rate and trade openness have significant effect on industrial sector growth. Based on Joahansen cointegration and Granger causality results, Mohsen et al., (2015), concluded relevancy of gross fixed capital formation, manufactured exports, population growth rate and agricultural output and oil prices in industrial sector output growth in Syria. While using the panel generalized method of moments Sertic et al., (2015) concluded that domestic demand, industrial production, real effective exchange rate, labor cost and dummy variable for economic crisis ${ }^{i}$ have significant effect on manufacturing industry exports in European Union. Martinaitytė and Kregždaitė (2015) used data for period 2003-2013, for

Value 1 was assigned the year when there is any economic crisis in any country of European Union, otherwise 0 values were assigned. 
finding out factors affecting creative development industries in Lithuania. They defined the creative industries as the area of overlap between culture, technology, science and commerce. They involved the supply of goods and services that have included a substantial element of artistic and intellectual activities associated with a vital role in social and human development.

\section{Data}

Time series data from 1975 to 2015, is employed for conducting the empirical analysis. The data is taken from World Bank World Development Indicators. Two factors determined the choice of sample period: (a) disintegration of the country in 1971, and (b) availability of the data. Trade openness data is not readily available. It is generated by scaling the sum of exports and imports with gross domestic product.

\section{Sectoral Growth Models}

The models we estimate for finding out factors determining sectoral growth in Pakistan are

$$
y_{t}^{s}=\alpha+\varphi_{1} c p i_{t}+\varphi_{2} f d_{t}+\varphi_{3} f d i_{t}+\varphi_{4} g n e_{t}+\varphi_{5} k_{t}+\varphi_{6} r e m_{t}+\varphi_{7} t o_{t}+\varepsilon_{t}
$$

The factors determining services sector growth $\left(y_{t}^{s}\right)$ are inflation $\left(c p i_{t}\right)$, foreign direct investment $\left(f d i_{t}\right)$, gross national expenditures $\left(g n e_{t}\right)$, gross fixed capital formation $\left(k_{t}\right)$, domestic credit to private sector $\left(f d_{t}\right)$, personal remittance $\left(\right.$ rem $\left._{t}\right)$ and trade openness $\left(t_{t}\right)$.

ARDL version of equation (1) is as under:

$$
\begin{aligned}
& \Delta y_{t}^{s}=\alpha+\sum_{i=1}^{p} \varphi_{1 i} \Delta y_{t-i}^{s}+\sum_{i=0}^{p} \varphi_{2 i} \Delta c p i_{t-i}+\sum_{i=0}^{p} \varphi_{3 i} \Delta f d_{t-i}+\sum_{i=0}^{p} \varphi_{4 i} \Delta f d i_{t-i}+\sum_{i=0}^{p} \varphi_{5} \Delta g n e_{t-i}+ \\
& \sum_{i=0}^{p} \varphi_{6 i} \Delta k_{t}+\sum_{i=0}^{p} \varphi_{7 i} \Delta r e m_{t-i}+\sum_{i=0}^{p} \varphi_{8 i} \Delta t o_{t-i}+\varphi_{9} y_{t-1}^{s}+\varphi_{10} c p i_{t-1}+\varphi_{11} f d_{t-1}+\varphi_{12} f d i_{t-1}+\varphi_{13} g n e_{t-1} \\
& +\varphi_{14} k_{t-1}+\varphi_{15} \operatorname{rem}_{t-1}+\varphi_{16} t o_{t-1}+\varepsilon_{t}
\end{aligned}
$$

$\Delta$ represents first difference operator. $\varphi_{1 i}, \varphi_{2 i}, \varphi_{3 i}, \varphi_{4 i}, \varphi_{5 i}, \varphi_{6 i}, \varphi_{7 i}$ and $\varphi_{8 i}$ represent short run dynamics of the model and $\varphi_{9 i}, \varphi_{10}, \varphi_{11}, \varphi_{12}, \varphi_{13}, \varphi_{14}, \varphi_{15}$, and $\varphi_{16}$ indicate long run association. $p$ denotes optimal lag length.

The null hypothesis tested is:

$H_{0}: \varphi_{9 i}=\varphi_{10}=\varphi_{11}=\varphi_{12}=\varphi_{13}=\varphi_{14}=\varphi_{15}=\varphi_{16}=0$ (no long run connection) against the alternative hypothesis:

$H_{a}: \varphi_{9 i} \neq \varphi_{10} \neq \varphi_{11} \neq \varphi_{12} \neq \varphi_{13} \neq \varphi_{14} \neq \varphi_{15} \neq \varphi_{16} \neq 0$ (there is long run connection)

Agriculture sector output growth equation is:

$y_{t}^{a}=\alpha+\alpha_{1} c p i_{t}+\alpha_{2} k_{t}+\alpha_{3} g n e_{t}+\alpha_{4}$ pop $_{t}+\alpha_{5} r e m_{t}+\alpha_{6} t o_{t}+\alpha_{7} p c l_{t}+$ $\alpha_{8} g d p_{t}+\alpha_{9} f d i_{t}+\epsilon_{t}$ 
$y_{t}^{a}$ represents an agriculture sector output growth. Independent variables are inflation $\left(c p i_{t}\right)$, gross fixed capital formation $\left(k_{t}\right)$, gross national expenditures $\left(g_{n} e_{t}\right)$, remittances $\left(\right.$ rem $\left._{t}\right)$, foreign trade $\left(t o_{t}\right)$, permanent crops land $\left(p c l_{t}\right)$, gross domestic product $\left(g d p_{t}\right)$, total population $\left(p o p_{t}\right)$ and foreign direct investment $\left(f d i_{t}\right)$.

ARDL version of equation (3) is:

$\Delta y_{t}^{a}=\alpha+\sum_{i=1}^{p} \alpha_{1 i} \Delta y_{t-i}^{a}+\sum_{i=0}^{p} \alpha_{2 i} \Delta c p i_{t-i}+\sum_{i=0}^{p} \alpha_{3 i} \Delta k_{t-i}+$

$\sum_{i=0}^{p} \alpha_{4 i}$ gne $_{t-i}+\sum_{i=0}^{p} \alpha_{5 i}$ pop $_{t-i}+\sum_{i=0}^{p} \alpha_{6 i} \Delta$ rem $_{t-i}+\sum_{i=0}^{p} \alpha_{7 i} \Delta t o_{t-i}+$

$\sum_{i=0}^{p} \alpha_{8 i} p l_{t-i}+\sum_{i=0}^{p} \alpha_{9 i} \Delta g d p_{t-i}+\sum_{i=0}^{p} \alpha_{10 i} \Delta f d i_{t-i}+\alpha_{11} y_{t-1}^{a}+$

$\alpha_{12}$ cpi $_{t-1}+\alpha_{13} k_{t-1}+\alpha_{14}$ gne $_{t-1}+\alpha_{15}$ pop $_{t-1}+\alpha_{16}$ rem $_{t-1}+\alpha_{17}$ to $_{t-1}+$

$\alpha_{18} p c l_{t-1}+\alpha_{19} g d p_{t-1}+\alpha_{20} f d i_{t-1}+\varepsilon_{t}$

$\alpha_{1 i} \alpha_{2 i}, \alpha_{3 i}, \alpha_{4 i}, \alpha_{5 i}, \alpha_{6 i}, \alpha_{7 i}, \alpha_{8 i}, \alpha_{9 i}, \alpha_{10 i}$ show short run dynamics of the model

and $\alpha_{11}, \alpha_{12}, \alpha_{13}, \alpha_{14}, \alpha_{15}, \alpha_{16}, \alpha_{17}, \alpha_{18}, \alpha_{19}$ and $\alpha_{20}$, indicate long run association.

The null hypothesis tested is:

$H_{0}: \alpha_{11}=\alpha_{12}=\alpha_{13}=\alpha_{14}=\alpha_{15}=\alpha_{16}=\alpha_{17}=\alpha_{18}=\alpha_{19}=\alpha_{20}=0$ (no long run

association)

against the alternative hypothesis:

$H_{a}: \alpha_{11} \neq \alpha_{12} \neq \alpha_{13} \neq \alpha_{14} \neq \alpha_{15} \neq \alpha_{16} \neq \alpha_{17} \neq \alpha_{18} \neq \alpha_{19} \neq \alpha_{20} \neq 0$ (there is long run association)

Industrial sector growth equation is given as:

$y_{t}^{i}=\alpha+\gamma_{1} e d_{t}+\gamma_{2} f d i_{t}+\gamma_{3} t o_{t}+\gamma_{4} f d_{t}+\gamma_{5} g n e_{t}+\gamma_{6} c p i_{t}+\gamma_{7} r e m_{t}+\gamma_{8} k_{t}+\varepsilon_{t}$

Equation (5) shows determinants of industrial sector growth $\left(y_{t}^{i}\right)$ which include: external debt $\left(e d_{t}\right)$, foreign direct investment $\left(f d i_{t}\right)$, foreign trade ( $\left.t o_{t}\right)$, domestic credit to private sector $\left(f d_{t}\right)$, government expenditures $\left(g n e_{t}\right)$, inflation $\left(\mathrm{cpi}_{t}\right)$, personal remittances $\left(\mathrm{rem}_{t}\right)$ and gross fixed capital formation $\left(k_{t}\right)$.

ARDL version of equation (5) is:

$$
\begin{aligned}
& \Delta y_{t}^{i}=\alpha+\sum_{i=1}^{p} \gamma_{1 i} \Delta y_{t-i}^{i}+\sum_{i=0}^{p} \gamma_{2 i} \Delta e d_{t-i}+\sum_{i=0}^{p} \gamma_{3 i} \Delta f d i_{t-i}+\sum_{i=0}^{p} \gamma_{4 i} \Delta t o_{t-i}+\sum_{i=0}^{p} \gamma_{5 i} \Delta f d_{t-i}+ \\
& \sum_{i=0}^{p} \gamma_{6 i} \Delta g n e_{t}+\sum_{i=0}^{p} \gamma_{7 i} \Delta c p i_{t-i}+\sum_{i=0}^{p} \gamma_{8 i} \Delta \operatorname{rem}_{t-i}+\sum_{i=0}^{p} \gamma_{9 i} \Delta k_{t-i}+\gamma_{10} y_{t-1}^{i}+\gamma_{11} e d_{t-1}+
\end{aligned}
$$

$\gamma_{12} f d i_{t-1}+\gamma_{13} t o_{t-1}+\gamma_{14} f d_{t-1}+\gamma_{15} g n e_{t-1}+\gamma_{16} c p i_{t-1}+\gamma_{17}$ rem $_{t-1}+\gamma_{18} k_{t-1}+\varepsilon_{t}$

$\gamma_{1 i}, \gamma_{2 i}, \gamma_{3 i}, \gamma_{4 i}, \gamma_{5 i}, \gamma_{6 i}, \gamma_{7 i}, \gamma_{8 i}$ and $\gamma_{9 i}$ showed short run dynamics of the model and $\gamma_{10}, \gamma_{11}, \gamma_{12}, \gamma_{13}, \gamma_{14}, \gamma_{15}, \gamma_{16}, \gamma_{17}, \gamma_{18}$ indicate long run association. Null hypothesis tested is:

$H_{0}: \gamma_{10}=\gamma_{11}=\gamma_{12}=\gamma_{13}=\gamma_{14}=\gamma_{15}=\gamma_{16}=\gamma_{17}=\gamma_{18}=0$ (no long run relationship) against alternative hypothesis: 
$H_{a}: \gamma_{10} \neq \gamma_{11} \neq \gamma_{12} \neq \gamma_{13} \neq \gamma_{14} \neq \gamma_{15} \neq \gamma_{16} \neq \gamma_{17} \neq \gamma_{18} \neq 0$ (there is long run relationship)

\section{Estimation Method and Unit Root Test}

Auto regressive distributed lag (ARDL) with general to specific approach is employed for identifying factors having significant effect on sectoral growth in Pakistan. Although ARDL does not require to check time series properties of the variables before using ARDL yet it is important to do so because critical F-statistics given by Pesaran et al., (2001) used for testing presence of long run relationship becomes invalid for integrating order $I(2)$ and beyond (Oyakhilomen \& Zibah, 2014).

Augmented Dickey Fuller test is used for testing time series properties of the variables. Results given in table 5.1 indicate that $y_{t}, c p i_{t}, f d i_{t}$ and $t o_{t}$ are intercept stationary in level. $y_{t}, f d i_{t}$ and $p_{0} p_{t}$ are intercept plus trend stationary in level. All the remaining variables are nonstationary in level and first difference which validates using $F$-statistic for testing presence of long run relationship among the variables for each sector using auto regressive distributed laga pproach is valid.

Table 1.1 ADF Unit Root Test

\begin{tabular}{|c|c|c|c|c|}
\hline \multirow[t]{2}{*}{ Variables } & \multicolumn{2}{|c|}{ Level } & \multicolumn{2}{|c|}{ First Difference } \\
\hline & Intercept & $\begin{array}{c}\text { Trend \& } \\
\text { Intercept }\end{array}$ & Intercept & $\begin{array}{l}\text { Trend \& } \\
\text { Intercept }\end{array}$ \\
\hline$y_{t}$ & $-4.04 *$ & $-4.65^{*}$ & $-9.21 *$ & $-9.08 *$ \\
\hline$y_{t}^{a}$ & -1.77 & -1.69 & $-5.97 *$ & $-6.16^{*}$ \\
\hline$y_{t}^{i}$ & -2.57 & -2.81 & $-7.02 *$ & $-7.04 *$ \\
\hline$y_{t}^{s}$ & -1.50 & -3.05 & $-4.19 *$ & $-4.27 *$ \\
\hline$c p i_{t}$ & $-2.86^{* *}$ & -2.76 & $-7.44^{*}$ & $-7.36^{*}$ \\
\hline$e d_{t}$ & -0.76 & -1.16 & $-4.83 *$ & $-4.81 *$ \\
\hline$f d i_{t}$ & $-2.79 * *$ & $-5.30 *$ & $-5.40^{*}$ & $-4.47 *$ \\
\hline$k_{t}$ & -1.47 & -2.39 & $-5.92 *$ & $-5.83 *$ \\
\hline$g n e_{t}$ & -1.80 & -1.92 & $-6.78 *$ & $-6.72 *$ \\
\hline rem $_{t}$ & -1.44 & -1.58 & $-5.77 *$ & $-5.71 *$ \\
\hline$f d_{t}$ & -0.86 & -1.25 & $-5.29 *$ & $-5.57 *$ \\
\hline$t o_{t}$ & $-3.01 * *$ & -2.97 & $-7.45^{*}$ & $-7.55^{*}$ \\
\hline$p c l_{t}$ & -2.40 & -1.21 & $-5.30 *$ & $-5.76^{*}$ \\
\hline pop & -2.10 & $-5.1^{*}$ & -2.02 & -2.22 \\
\hline $10 \%$ critical values & -2.60 & -3.19 & -2.61 & -3.20 \\
\hline $1 \%$ critical values & -3.61 & -4.21 & -3.62 & -4.22 \\
\hline
\end{tabular}


Note: $y_{t}, y_{t}^{a}, y_{t}^{i}, y_{t}^{s}, c p i_{t}, e d_{t}, f d i_{t}, k_{t}, g n e_{t}, r e m_{t}, f d_{t}, t o_{t}, p c l_{t}$ represent GDP growth, agricultural, industrial and services sector output growth, inflation, external debt scaled by gross national expenditures, net foreign direct investment, gross fixed capital formation, gross national expenditures, personal remittances received, domestic credit to private sector, money and quasi money, real exchange rate, trade openness, total population and permanent crop land respectively. * and $* *$ represent one percent and ten percent significance level.

\section{Results}

General to specific approach is adopted for finding out the factors having relevancy in determining sectoral growth in Pakistan. According to this approach sectoral equations (1,3 and 5) in auto regressive distributed lag specification are estimated in their general form. The variables that appear insignificant are dropped and the equations are re-estimated. This process continued the parsimonious models with estimated parameters significant are obtained. Table 5.3 contains long run estimates of specific models. ${ }^{\text {ii }}$

Table 1.2: $F$-statistic of Cointegration Relationship

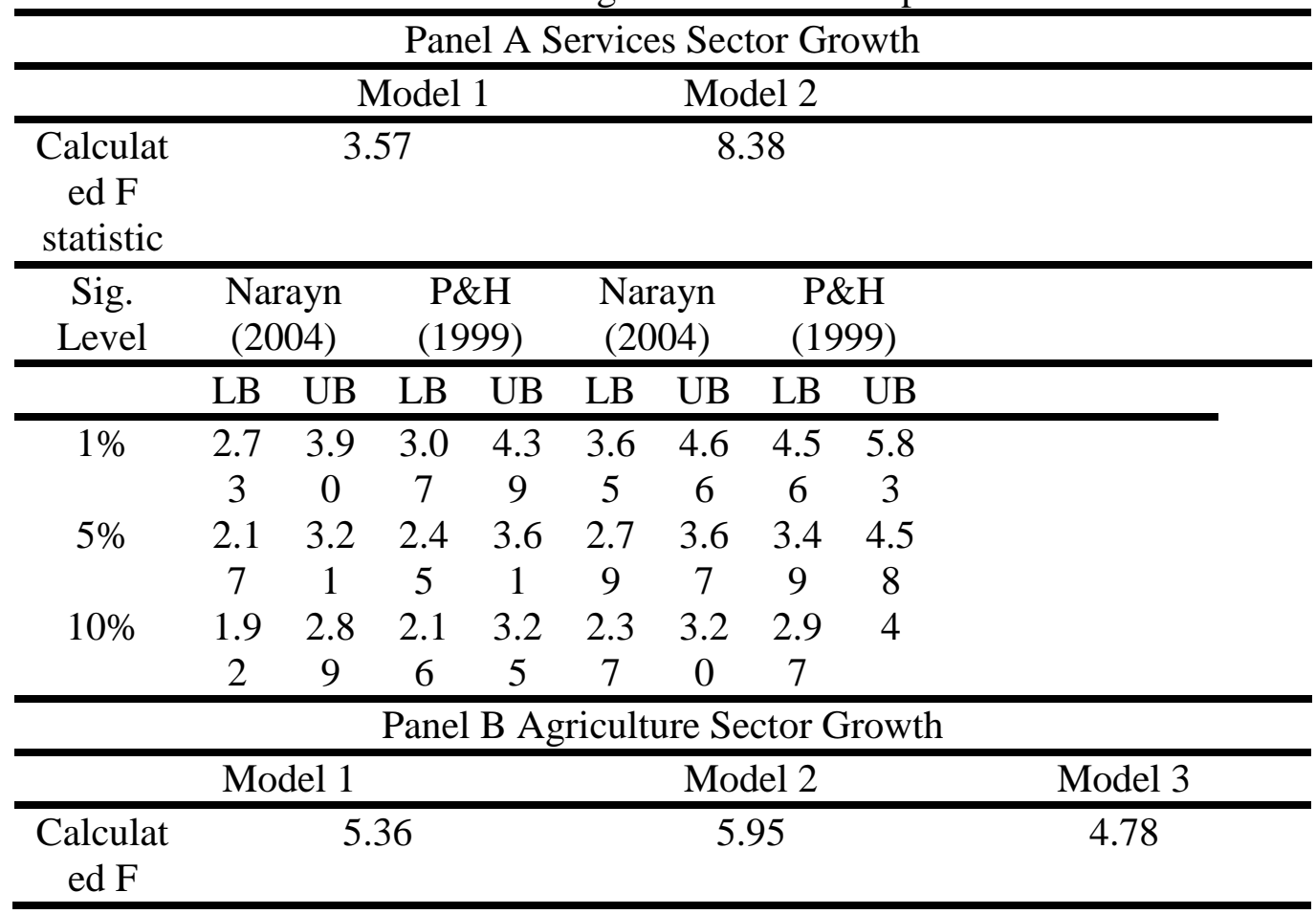

ii Long run and short run estimates of dropped models are given in appendix B and C. Appendix A on the other hand show information criterion results for selecting optimal lag length of all the estimated models. 


\begin{tabular}{|c|c|c|c|c|c|c|c|c|c|c|c|c|}
\hline \multicolumn{13}{|l|}{ statistic } \\
\hline \multirow[t]{2}{*}{$\begin{array}{c}\text { Sig. } \\
\text { Level }\end{array}$} & \multicolumn{2}{|c|}{$\begin{array}{l}\text { Narayn } \\
(2004)\end{array}$} & \multicolumn{2}{|c|}{$\begin{array}{c}\text { P\&H } \\
(1999)\end{array}$} & \multicolumn{2}{|c|}{$\begin{array}{l}\text { Narayn } \\
(2004)\end{array}$} & \multicolumn{2}{|c|}{$\begin{array}{c}\text { P\&H } \\
(1999)\end{array}$} & \multicolumn{2}{|c|}{$\begin{array}{c}\text { Narayn } \\
(2004)\end{array}$} & \multicolumn{2}{|c|}{$\begin{array}{l}\text { P\&H } \\
(1999)\end{array}$} \\
\hline & $\mathrm{LB}$ & UB & LB & UB & LB & UB & $\mathrm{LB}$ & UB & LB & UB & $\mathrm{LB}$ & UB \\
\hline \multirow[t]{2}{*}{$1 \%$} & 2.5 & 3.6 & 2.7 & 4.0 & 2.7 & 3.9 & 3.0 & 4.3 & 3.6 & 4.6 & 4.5 & 5.8 \\
\hline & 0 & 8 & 6 & 5 & 3 & 0 & 7 & 9 & 5 & 6 & 6 & 3 \\
\hline \multirow[t]{2}{*}{$5 \%$} & 2.0 & 2.0 & 2.2 & 3.3 & 2.1 & 3.2 & 2.4 & 3.6 & 2.7 & 3.6 & 3.4 & 4.5 \\
\hline & 4 & 8 & 4 & 9 & 7 & 1 & 5 & 1 & 9 & 7 & 9 & 8 \\
\hline \multirow[t]{2}{*}{$10 \%$} & 1.8 & 2.8 & 1.9 & 3.0 & 1.9 & 2,8 & 2.1 & 3.2 & 2.3 & 3.2 & 2.9 & 4 \\
\hline & 0 & 0 & 8 & 8 & 2 & 9 & 6 & 5 & 7 & 0 & 7 & \\
\hline \multicolumn{13}{|c|}{ Panel C Industrial Sector Growth } \\
\hline \multicolumn{5}{|c|}{ Model 1} & \multicolumn{4}{|c|}{ Model 2} & & & & \\
\hline $\begin{array}{c}\text { Calculat } \\
\text { ed F } \\
\text { statistic }\end{array}$ & \multicolumn{4}{|c|}{3.98} & \multicolumn{4}{|c|}{6.45} & & & & \\
\hline $\begin{array}{l}\text { Sig. } \\
\text { Level }\end{array}$ & \multicolumn{2}{|c|}{$\begin{array}{l}\text { Narayn } \\
(2004)\end{array}$} & \multicolumn{2}{|c|}{$\begin{array}{l}\text { P\&H } \\
(1999)\end{array}$} & \multicolumn{2}{|c|}{$\begin{array}{l}\text { Narayn } \\
(2004)\end{array}$} & \multicolumn{2}{|c|}{$\begin{array}{l}\text { P\&H } \\
(1999)\end{array}$} & & & & \\
\hline \multirow{3}{*}{$1 \%$} & LB & UB & LB & UB & LB & UB & LB & UB & & & & \\
\hline & 2.6 & 3.7 & 2.9 & 4.1 & 3.2 & 4.3 & 3.9 & 5.2 & & & & \\
\hline & 2 & 7 & 1 & 9 & 9 & 7 & 5 & 4 & & & & \\
\hline \multirow[t]{2}{*}{$5 \%$} & 1.9 & 3.0 & 2.3 & 3.5 & 2.5 & 3.4 & 3.0 & 4.1 & & & & \\
\hline & 8 & 4 & 4 & 0 & 6 & 9 & 7 & 9 & & & & \\
\hline \multirow[t]{2}{*}{$10 \%$} & 1.7 & 2.7 & 2.0 & 3.1 & 2.2 & 3.0 & 2.6 & 3.1 & & & & \\
\hline & 6 & 7 & 6 & 7 & 0 & 9 & 5 & 7 & & & & \\
\hline
\end{tabular}

Note: Sig, P\&H, LB and UB refers to significance, Pesaran and Hashim, upper bound and lower bound respectively.

Calculated $F$-statistics for determining presence of cointegrating relationship in sectoral growth equations are given in Table 5.2. Since calculated $F$ statistic exceed one percent upper bound critical values hence null of no cointegrating relationship among the dependent and independent variables in sectoral growth equations is rejected. Results of specific models in table 5.3 further reveal that consumer price index, foreign direct investment and remittances received are the relevant determinants of services sector

Table 1.3 Lon Run Estimates of Specific Models ${ }^{\mathrm{iii}}$

\begin{tabular}{l} 
Services Sector Agriculture Industrial Sector \\
\hline iii \\
$\begin{array}{l}\text { The major macroeconomic indicators affecting sectoral growth are identified from } \\
\text { empirical growth literature around the world, and then, general to specific approach is } \\
\text { adopted for finding as to which of these macroeconomic indicators are relevantly } \\
\text { determinants of growth in Pakistan. }\end{array}$
\end{tabular}




\begin{tabular}{cccc}
\hline \multicolumn{3}{c}{ Sector } \\
\hline Variable & Model 2 & Model 3 & Model 2 \\
\hline cpi $_{t}$ & $-0.02(3.09)^{a}$ & $0.03(3.52)^{a}$ & $0.06(2.37)^{a}$ \\
$f d_{t}$ & & & $0.23(3.98)^{a}$ \\
$f d i_{t}$ & $0.09(15.81)^{a}$ & & $-0.08(5.21)^{a}$ \\
gne $_{t}$ & & & $-1.95(6.33)^{a}$ \\
$k_{t}$ & & $-0.28(3.41)^{a}$ & \\
pop $_{t}$ & & $5.77(1.81)^{a}$ & \\
rem $_{t}$ & $0.07(8.08)^{a}$ & & \\
\hline
\end{tabular}

Note: t-values are given in parenthesis. $a$ and $b$ showing the significance of estimated parameters at five and ten percent significance level respectively. growth in Pakistan.

Specific model for agriculture sector growth shows consumer price index, gross fixed capital formation and population are the relevant determinants of agriculture sector growth in ARDL framework.

Specific model for industrial sector growth results indicate the inflation, domestic credit, foreign direct investment, and gross national expenditures are the relevant determinants of industrial sector growth in Pakistan in ARDL framework. Inflation and credit extended to private sector augment industrial sector growth while foreign direct investment retards it.

Table 5.4 represents short run estimates of specific sectoral growth models. It is an evident from the table that services sector growth is positively influenced by its own lag. Other factors that influence services sector growth in short run are foreign direct investment and remittances. Foreign direct investment effect on the growth is positive as well as negative. Remittances effect on the other hand is positive in short run. Error correction term is the significant and negative which means quick adjustment of deviation towards their equilibrium level.

Short run estimates of agriculture sector growth indicate that it is negatively affected by its own lag. Other factors that have relevancy for agriculture sector growth in short run are consumer price index and gross fixed capital formation and their effect is positive and negatively respectively. Error correction term is significant and negative. It indicates that ninety percent of deviations from equilibrium are adjusted within one year.

Table 1.4 Error Correction Model of Specific Sectoral Growth Models

\begin{tabular}{lrrr}
\hline & Services Sector & $\begin{array}{l}\text { Agriculture } \\
\text { Sector }\end{array}$ & Industrial Sector \\
\hline Variable & Model 2 & Model 3 & Model 2 \\
\hline$\Delta y_{t-1}^{a}$ & & $-0.26(-1.75)^{b}$ & \\
$\Delta y_{t-1}^{s}$ & $0.21(1.80)^{b}$ & & \\
\hline
\end{tabular}




\begin{tabular}{|c|c|c|c|}
\hline$\Delta c p i_{t}$ & & $0.01(1.91)^{b}$ & $0.09(5.13)^{a}$ \\
\hline$\Delta f d_{t}$ & & & $0.18(2.26)^{a}$ \\
\hline$\Delta f d i_{t}$ & $0.04(4.95)^{a}$ & & $-0.03(-2.28)^{a}$ \\
\hline$\Delta f d i_{t-1}$ & $-0.04(-4.59)^{a}$ & & $0.03(1.94)^{b}$ \\
\hline$\Delta g n e_{t}$ & & & $-0.93(-3.13)^{a}$ \\
\hline$\Delta k_{t}$ & & $-0.28(-2.90)^{a}$ & \\
\hline$\Delta r e m_{t}$ & $0.04(4.05)^{a}$ & & \\
\hline$e c t_{t-1}$ & $-1.71(-1.98)^{a}$ & $-0.90(-2.30)^{a}$ & $-0.69(-1.92)^{b}$ \\
\hline \multicolumn{4}{|c|}{ Diagnostic Tests } \\
\hline $\begin{array}{l}\text { F Statistic LM } \\
\text { Test }\end{array}$ & $2.14(0.19)$ & $0.35(0.70)$ & $0.11(0.89)$ \\
\hline $\begin{array}{l}\text { F-Statistic } \\
\text { ARCH }\end{array}$ & $2.04(0.16)$ & $0.02(0.88)$ & $0.89(0.35)$ \\
\hline F-Statistic White & $1.44(0.29)$ & $1.41(0.24)$ & $1.94(0.10)$ \\
\hline $\begin{array}{l}\text { F-Statistic JB } \\
\text { Test }\end{array}$ & $0.49(0.78)$ & $0.61(0.73)$ & $1.82(0.40)$ \\
\hline$R^{2}$ & 0.87 & 0.43 & 0.75 \\
\hline $\bar{R}^{2}$ & 0.58 & 0.31 & 0.62 \\
\hline
\end{tabular}

Note: $a$ and $b$ represent five percent and ten percent significance level.

Short run estimates of industrial sector growth are consumer price index, foreign direct investment, credit extended to private sector and gross national expenditures. Consumer price index and credit extended to private sector on industrial sector growth in short run is positive. Foreign direct investment effect on industrial sector growth is both positive and negative. In short run, gross national expenditure retard industry growth in the country. This may happen because of increase in government expenditure leave little for credit for industrial sector growth that explains negative estimate gross national expenditure here. The significant negative estimate of error correction term indicates that sixty-nine deviation from equilibrium level as adjusted within one year. Lower panel of the table show that residual satisfy all their properties. They are neither serially correlated nor suffer from heteroscedasticity issue.

Figure 1: Specific Models Stability Tests 

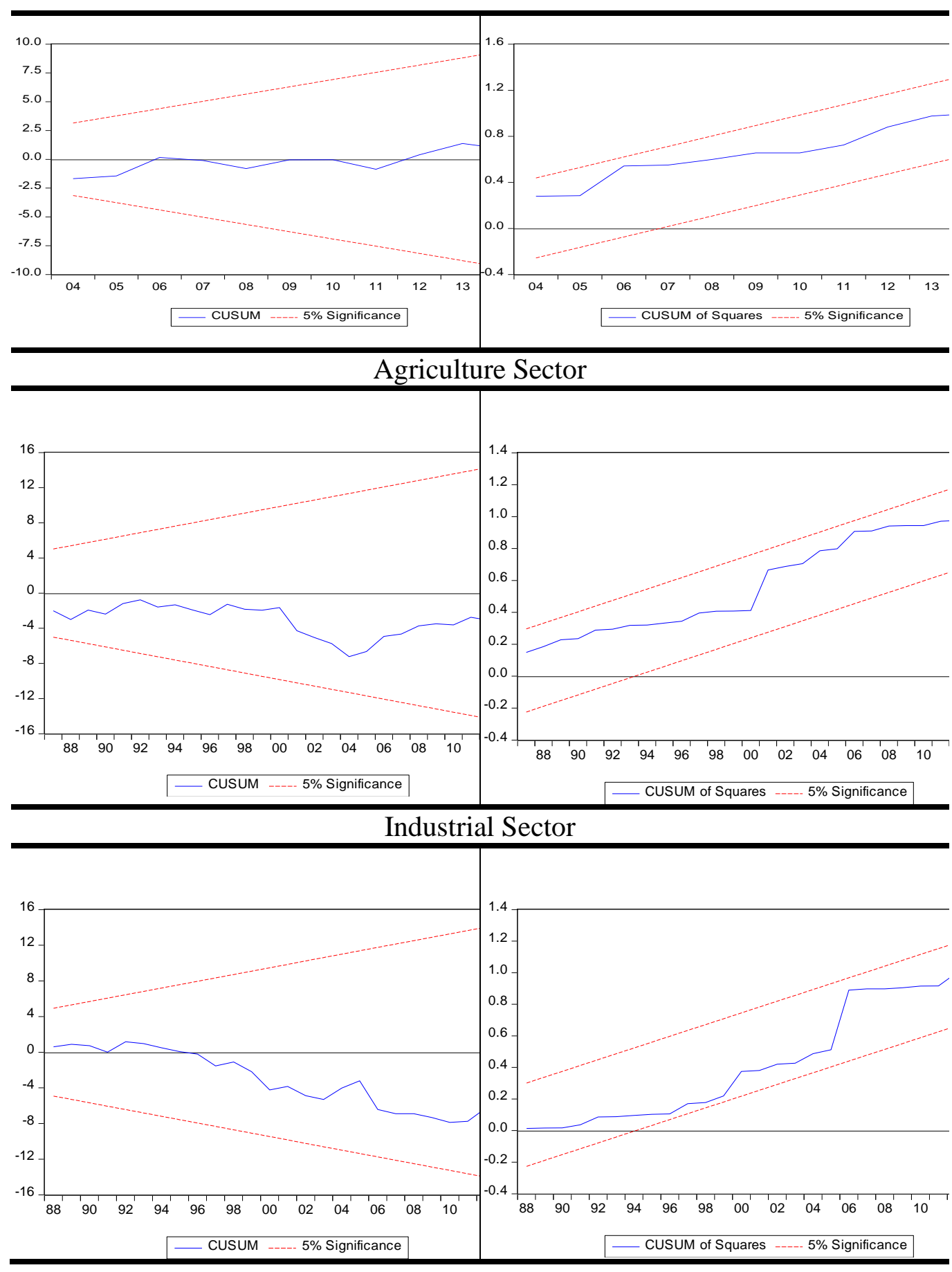

Note: CUSUM and CUSUM of Square represents Cumulative Sum of Recursive Residuals amnd Cumulative Residuals respectively.

Stability of the estimated model is tested using Cumulative sum of recursive residuals and cumulative sum of square of recursive residuals. The models suffer from instability if the estimated CUSUM and CUSUMSQ 
estimated cross their upper and lower bound critical values. It is apparent from figure 1 that estimated CUMSUM and CUSUMSQ do not cross their critical lines. Hence, we conclude that the estimated specific sectoral growth models do not suffer from

structural breaks and are stable.

\section{Conclusion}

In this paper, we employed ARDL bound testing approach for finding out factors determining sectoral growth in Pakistan. Two factors that determined choice of the sample period are (a) disintegration of the country in 1971, and (b) data on most of the variable is available after 1975. Autoregressive distributed lag approach was employed for conducting the analysis. Results revealed that null hypothesis of no long relationship among the sectoral equation variables as rejected. Results further showed that services sector growth is affected by consumer price index, foreign direct investment and remittances received. Consumer price index, gross fixed capital formation and population are the relevant determinants of agriculture sector growth in long run. Industrial sector on the other hand is influenced by consumer price index, foreign direct investment, credit extended to private sector and gross national expenditures. Error correction estimates are correctly signed and highly significant which imply that the system converges to its long run equilibrium and deviations from equilibrium are transitory and converge quickly to their long run equilibrium level. Based on the results, it is recommended that the relevant authorities augment those factors that cause sectoral growth and control those that reduce it.

In this research paper, we employed ARDL bound testing approach for finding out the factors having relevancy in determining sectoral growth in Pakistan. Objective was to find out the factors that positive/negative effect of sectoral growth. In order to conduct the analysis, aggregated data was employed. The future research on the same topic may use the disaggregated data (sector specific foreign direct investment and other variables) for finding out relevancy of factors in determining sectoral growth in the country. The research may further be extended by focusing sub-sectoral growth in the country.

\section{References}

Ahmed, K., \& Heng, A.C.T. (2012). Determinants of agriculture productivity in Pakistan. International Research Journal of Finance and Economics, Vol. 95, 163-172.

Burja, C. (2015). The influence of relevant factors on farm output value: an analysis of agriculture holdings from Romania. Annals of the Constantin Brancusi University of Targu Jiu, Economy Series, Vol. 2(1), 124-129.

Chebil, A., Frija, A. and Alyani, R. (2015). Measurement of total factor productivity and its determinants: case of wheat sector in Tunisia. 
International Center for Agricultural Research in the Dry Areas, Working Paper Series 934, 1-11.

Enu, P. and Obeng, P.A. (2013). Which macro factors influence agricultural production in Ghana? Academic Research Journal, Vol. 4(5), 333-346.

Gebru (2015). The determinants of economic Growth in Ethiopia: A Time Series Analysis. Master Thesis, Addis Ababa University.

Gordon J. and Gupta, P. (2003). Understanding India's services revolution, IMF-NCAER conference, a tale of two giants: India and China's experience with reform. Retrieved from www.imf.org/external/np/apd/seminars/2003/newdelhi/gordon

Jain, D., Nair, K.S. and Jain, V. (2015). Factors affecting GDP (manufacturing, services, industry): an Indian perspective, Annual Research Journal of Symbiosis Centre for Management Studies Pune, Vol. 3, 38-56.

Kathuria, V., Raj, R.S.N. and Sen, K. (2010) Human Capital and Manufacturing Productivity Growth in India. International Conference on: Science, Technology and Economy: Human Capital and Development (Annual Conference of IASSI \& Knowledge Forum Hosted by IIT Bombay). Retrieved from http://fgks.in/images/pdf/papers/136.

Khaledi, K. and Shirazi, A.H. (2013). Estimates of factors affecting economic growth in the agricultural sector in the fifth development plan of Iran (emphasis on investment). World Applied Sciences Journal, Vol. 22(10), 1492-1499.

Martinaitytė, E. and Kregždaitè, R. (2015). The factors of creative industries development in now a day's stage. Economics and Sociology, 8(1), 55-70.

Mohsen, A.S., Chua, S.Y., and Sab, C.N.C. (2015). Determinants of industrial output in Syria. Journal of Economic Structures, Vol. 4(19), 1-12.

Nitisha (2002) Factors that Affect the Economic Growth of a Country. Retrieved from http://www.economicsdiscussion.net/economic-growth/5factors-that-affect-the-economic-growth-of-a-country/4199

Odhiambo, W., Nyangito, H.O. and Zuma, J. (2004). Sources and determinants of agricultural growth and productivity in Kenya. Kenya Institute for Public Policy Research and Analysis (KIPPRA) Discussion Paper no.34, 1-67.

Otalu, J.A. and Andrew, K. (2015). An assessment of the determinants of industrial sector growth In Nigeria. Journal of Research in Business and Management, Vol. 3(7), 01-09.

Oyakhilomen, O., and Zibah, R.G. (2014) Agricultural production and economic growth in Nigeria: implication for rural poverty alleviation. Quarterly Journal of International Agriculture, Vol. 53(3), 207-223.

Palmer, N.T. (2012) The Importance of Economic Growth. Certified Public Accounts, 1-6.

Pesaran, M.H., Shin, Y., and Smith, R. (2001). Bounds testing approaches to the analysis of level relationships. Journal of Applied Econometrics, Vol. $16,289-326$. 
Rashid, A. (2010) Sectoral linkages; identifying the key growth stimulating sector of the Pakistan Economy. Retrieved from http://mpra.ub.unimuenchen.de/27210/

Rtic, M.B., Vučković, V. \& Peric, B.S. (2015). Determinants of manufacturing industry exports in European Union member states: a panel data analysis. Economic Research, Vol. 28(1) Doi:10.1080/1331677X.2015.1043781.

Setric, M.B., Vuckvoic, V., and Peric, B.S. (2015). Determinants of manufacturing industry exports in European member states: a panel data analysis. Economic Research-Economska Istrazivanja, Vol. 28(1), 384397.

Singariya, M. R. Naval S. C. (2016). An empirical study of inter-sectoral linkages and economic growth in India. American Journal of Rural Development, Vol. 4(4), 78-84.

Singh, M. and Kaur, K. (2014). India's services sector and its determinants: an empirical investigation. Journal of Economics and Development Studies, Vol. 2(2), 385-406.

Singh, L. and Singh, N. (2016) Economic transformation of a developing economy: The Experience of Punjab, India. A book chapter in Indian Studies in Business and Economics.

Sola, O., Obamuyi, T.M., Adeknujo, F.O., and Ogunleye, E.O. (2013). Manufacturing performance in Nigeria: implication for sustainable development, Asian Economic and Financial Review, Vol. 3(9), 11951213.

Wu, Y. (2005). Service sector growth in China and India: A comparison. China: An International Journal, Vol. 5(1), 137-154.

Warr, P. (2012). The effect of research on agricultural productivity in Indonesia. Australian Center for International Agricultural Research (ACIAR). Retrieved from: https://aciar.gov.au/files/node/13434/fr2011_04_66539 


\section{Appendices}

Appendix A

Lag Selection Criterion

Services Sector Growth

\begin{tabular}{lcc}
\hline \multirow{2}{*}{ Lag Selection } & \multicolumn{2}{c}{ Model 2 } \\
\cline { 2 - 3 } & Lag 1 & Lag 2 \\
\hline AIC Estimate & -6.37 & -7.10 \\
$R^{2}$ Value & 0.88 & 0.97 \\
\hline
\end{tabular}

Agriculture Sector Growth

\begin{tabular}{lcc}
\hline Lag Selection & Model 3 \\
\hline & Lag 1 & Lag 2 \\
\hline AIC Estimate & -5.66 & -5.81 \\
$R^{2}$ Value & 0.92 & 0.93 \\
\hline
\end{tabular}

Industrial Sector Growth

\begin{tabular}{lll}
\hline Lag Selection & & Model 2 \\
\hline & Lag 1 & Lag 2 \\
\hline AIC Estimate & -4.94 & -5.19 \\
$R^{2}$ Value & 0.68 & 0.79 \\
\hline
\end{tabular}

Appendix B Long Run Estimates of Dropped Models

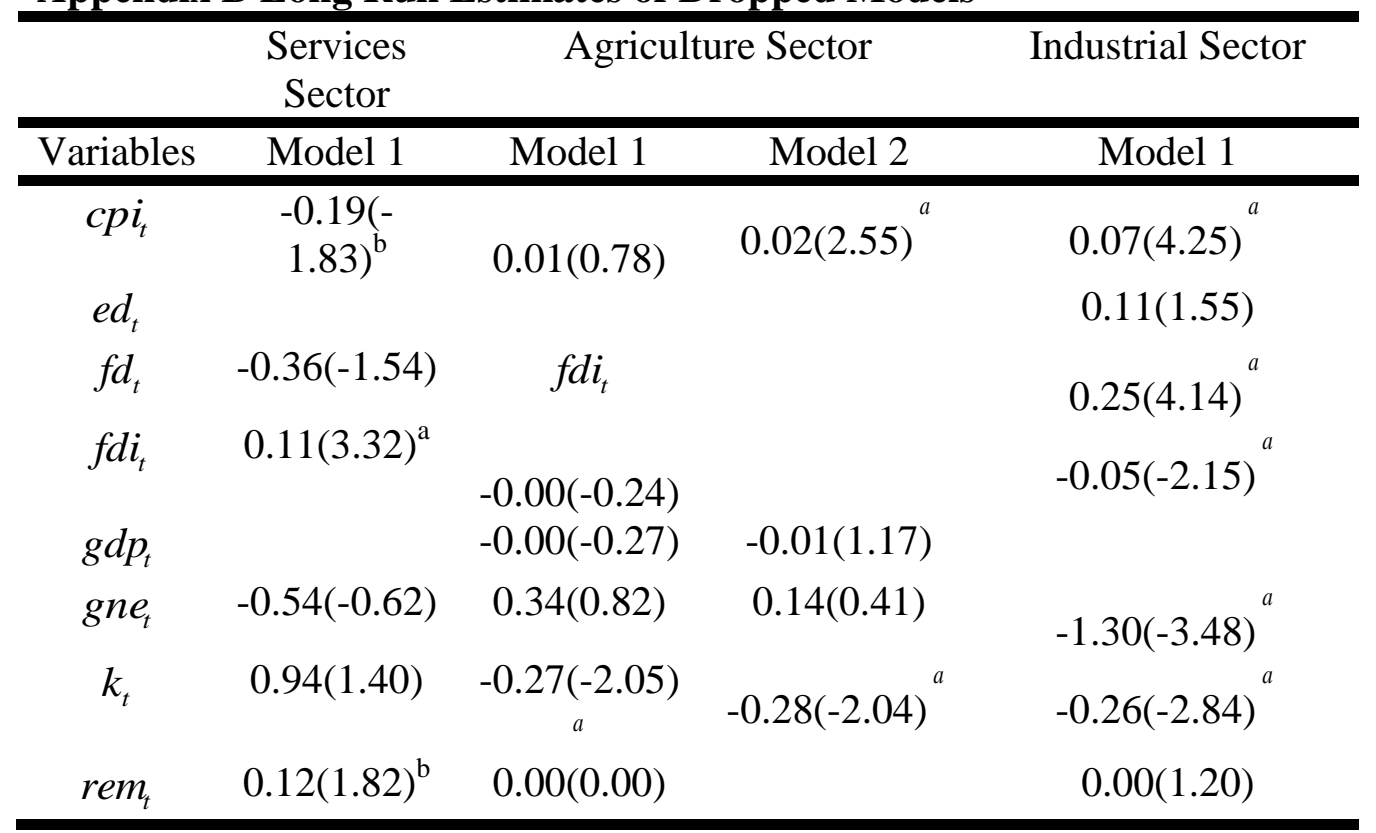




\begin{tabular}{|c|c|c|c|c|c|c|}
\hline $\begin{array}{c}p c l_{t} \\
p o p_{t} \\
t o_{t}\end{array}$ & $-0.22(-0.96)$ & \multicolumn{2}{|c|}{$\begin{array}{c}-0.25(-1.58) \\
52.62(1.96) \\
b \\
-0.23(-1.89) \\
b\end{array}$} & \multicolumn{2}{|c|}{$\begin{array}{l}-0.19(-1.12) \\
30.48(1.17) \\
-0.04(-0.49)\end{array}$} & $0.06(1.19)$ \\
\hline \multicolumn{7}{|c|}{$\begin{array}{l}\text { Note: t-values are given in parenthesis. } a \text { and } b \text { sho } \\
\text { estimated parameters at five and ten percent significanc } \\
\text { Appendix C Short Run Estimates Dropped Models }\end{array}$} \\
\hline & \multicolumn{2}{|c|}{$\begin{array}{c}\text { Services } \\
\text { Sector }\end{array}$} & \multicolumn{3}{|c|}{ Agriculture Sector } & $\begin{array}{l}\text { Industrial } \\
\text { Sector }\end{array}$ \\
\hline Variables & \multicolumn{2}{|c|}{ Model 1} & \multirow{2}{*}{\multicolumn{2}{|c|}{$\begin{array}{c}\text { Model1 } \\
-0.27(- \\
1.17)\end{array}$}} & \multirow{3}{*}{$\begin{array}{c}\text { Model } 2 \\
-0.28(-1.82) \\
b\end{array}$} & Model 1 \\
\hline$\Delta y_{t-1}^{a}$ & & & & & & \\
\hline$\Delta y_{t-1}^{s}$ & $-0.31(-2$ & $38)^{a}$ & \multirow{2}{*}{\multicolumn{2}{|c|}{$\begin{array}{c}0.03(1.96) \\
b\end{array}$}} & & \multirow[b]{2}{*}{$0.11(8.48)^{a}$} \\
\hline$\Delta c p i_{t}$ & $-0.04(-6$ & & & & $0.03(3.07)^{a}$ & \\
\hline$\Delta c p i_{t-1}$ & $-0.01(-2$ & & $\begin{array}{r}0.02(1 \\
b\end{array}$ & & $0.01(1.58)$ & $0.03(3.18)^{a}$ \\
\hline$\Delta e d_{t}$ & & & & & & $0.22(4.29)^{a}$ \\
\hline$\Delta e d_{t-1}$ & & & & & & $-0.29(-4.45)^{a}$ \\
\hline$\Delta f d_{t}$ & $-0.20(-6$ & $05)^{a}$ & & & & $0.18(3.29)^{a}$ \\
\hline$\Delta f d_{t-1}$ & $-0.08(-2$ & & & & & $0.15(2.75)^{a}$ \\
\hline$\Delta f d i_{t}$ & $0.02(4$. & & & & & \\
\hline$\Delta f d i_{t-1}$ & $-0.02(-3$ & & & & & $-0.02(2.21)^{a}$ \\
\hline$\Delta k_{t}$ & $0.13(3$. & & $\begin{array}{r}-0.18 \\
1.00\end{array}$ & & $-0.37(-3.71)^{a}$ & $0.23(3.26)^{a}$ \\
\hline$\Delta k_{t-1}$ & & & & & & $0.36(3.73)^{a}$ \\
\hline$\Delta g n e_{t}$ & $0.45(3$. & & & & & $-1.67(-6.95)^{a}$ \\
\hline$\Delta g n e_{t-1}$ & $0.54(4$. & & $\begin{array}{r}-0.22 \\
0.41\end{array}$ & & $0.58(1.85)^{b}$ & $-1.00(-3.68)^{a}$ \\
\hline$\Delta r e m_{t}$ & $0.01(-1$ & 20) & $0.01(0$ & & & $0.00(0.09)$ \\
\hline$\Delta p c l_{t}$ & & & $\begin{array}{l}-0.57 \\
2.58\end{array}$ & & $-0.36(-2.08)^{a}$ & \\
\hline
\end{tabular}




\begin{tabular}{|c|c|c|c|c|}
\hline$\Delta p o p_{t}$ & & $50.67(1.83)$ & $-0.23(-0.20)$ & \\
\hline$\Delta p o p_{t-1}$ & & $\begin{array}{c}b \\
-51.77(-\end{array}$ & & \\
\hline$\Delta t o_{t}$ & $-0.06(-1.69)^{b}$ & $\begin{array}{l}1.85)^{b} \\
-0.24(- \\
1.97)^{b}\end{array}$ & $-0.03(-0.33)$ & $0.24(4.19)^{a}$ \\
\hline$\Delta t o_{t-1}$ & & & & $0.19(2.83)^{a}$ \\
\hline$e c t_{t-1}$ & $-0.70(-2.00)^{a}$ & $\begin{array}{l}-1.25(- \\
3.16)^{a}\end{array}$ & $-1.27(-.40)^{a}$ & $-1.10(-3.40)^{a}$ \\
\hline \multicolumn{5}{|l|}{ Diagnostic } \\
\hline Tests & $1.42(0.29)$ & $0.67(0.52)$ & $0.12(0.88)$ & $1.39(0.38)$ \\
\hline F- statistic & $0.19(0.66)$ & $0.27(0.60)$ & $0.67(0.41)$ & $1.59(0.22)$ \\
\hline LM Test & $0.61(0.84)$ & $0.49(0.90)$ & $1.19(0.38)$ & $0.25(0.99)$ \\
\hline $\begin{array}{c}\text { F- statistic } \\
\text { ARCH }\end{array}$ & $7.70(0.02)$ & $3.19(0.20)$ & $1.07(0.60)$ & $0.53(0.23)$ \\
\hline \multicolumn{5}{|l|}{ F- statistic } \\
\hline \multicolumn{5}{|l|}{ White Test } \\
\hline \multicolumn{5}{|l|}{ F- statistic } \\
\hline Jarque- & & & & \\
\hline$R^{2}$ & 0.94 & 0.31 & & 0.93 \\
\hline $\bar{R}^{2}$ & 0.84 & 049 & & 0.74 \\
\hline
\end{tabular}

